\title{
Deepen Teaching Reform and Cultivate Cross-century Financial Management Talents
}

\author{
Qiang Ding \\ Suzhou Industrial Park Institute of Services Outsourcing, Suzhou, Jiangsu, China \\ squall.d@163.com
}

Keywords: teaching reform; cross-century; financial management talents

\begin{abstract}
At present, China's economy is developing at a rapid pace, and the employment situation of college graduates is severe. Many colleges and universities adhere to the employment-oriented educational philosophy and school-running philosophy to reform the traditional teaching methods with unique innovative thinking so as to enhance students' professionalism and professional skills and solve the problem of students' employment difficulties. This paper analyzes the deepening of teaching reform and training cross-century financial management talents.
\end{abstract}

\section{Introduction}

Currently, China's economy is developing rapidly, and all units are eager for talents. However, the demand for market talents and the cultivation of talents in universities often fail to achieve a perfect fit and unity, and university graduates are in a very embarrassing situation. Due to the rapid development of global technology, a large number of high-tech equipment has been widely used by enterprises, and the management model has been systematically updated, and the update of knowledge has not reached the enterprise's employment standards. With the rapid development of science and technology in the 21st century, the information age has become an indisputable fact, which requires the labor to have certain cultural knowledge and practical ability. Universities should strive to integrate professional ethics and social responsibility into the minds of students, add them to the goal of talent training, and carry out various forms of practice, so that students can fully exert their talents, sum up practical experience and enhance students' professional quality.

\section{Type of Talent Training Model}

In the stage of popularization of higher education, research universities are critical bases for the cultivation of high-level talents in the country. The main task is that cultivating innovative elites with broad basic knowledge, strong sense of innovation, and good self-study capacity, independent research ability and practical ability; teaching and research universities are mainly to cultivate talents with compound, applied and advanced skills.

\section{Marxist Structural Theory}

Marx divided the material production department into two major categories: the first category is the sum of the production and production materials departments, and the second category is the sum of the production and consumption data departments. The production process of the two major categories constitutes the production process of the whole society. This production process not only produces the material conditions on which human society depends, but also is the process of production relations in specific historical environments and economic conditions. The prerequisites for achieving balanced development of the two major categories are:

$$
\begin{gathered}
\mathrm{I}_{\mathrm{v}+\mathrm{m})}=\mathrm{II} \\
\mathrm{I}_{(\mathrm{C}+\mathrm{V}+\mathrm{M})}=\mathrm{I}_{\mathrm{C}}+\mathrm{II}_{\mathrm{C}} \\
\mathrm{II}_{(\mathrm{C}+\mathrm{V}+\mathrm{M})}=\mathrm{I}_{(\mathrm{V}+\mathrm{M})}+\mathrm{II}_{(\mathrm{Y}+\mathrm{M})}
\end{gathered}
$$


Table 1 Comparison of talent training, scientific and technological contributions and service society in different types of colleges and universities

\begin{tabular}{|c|c|c|c|c|}
\hline \multicolumn{2}{|c|}{ Type } & Talent training type & Scientific contribution & Service society \\
\hline \multicolumn{2}{|c|}{ Research university } & $\begin{array}{lr}\begin{array}{l}\text { Talents with } \\
\text { knowledge, }\end{array} & \text { eneral } \\
\text { elite, } \\
\text { innovative } & \text { (mainly } \\
\text { postgraduate } & \\
\text { education) } & \end{array}$ & $\begin{array}{l}\text { Technological } \\
\text { innovation research } \\
\text { and basic original } \\
\text { theory research }\end{array}$ & $\begin{array}{l}\text { Cultivating elite talents } \\
\text { and superior technological } \\
\text { and innovative talents, } \\
\text { Technological and } \\
\text { innovative contribution } \\
\text { and original theory }\end{array}$ \\
\hline \multicolumn{2}{|c|}{$\begin{array}{l}\text { Teaching and research } \\
\text { university }\end{array}$} & $\begin{array}{l}\text { Compound, applied, } \\
\text { and advanced skills } \\
\text { (postgraduate } \\
\text { education accounts for } \\
\text { a large proportion) }\end{array}$ & $\begin{array}{l}\text { Applied research and } \\
\text { technological } \\
\text { innovation research }\end{array}$ & $\begin{array}{lr}\text { Cultivate } & \text { advanced } \\
\text { technology } & \text { applications } \\
\text { and } & \text { technological } \\
\text { innovation } & \text { talents, } \\
\text { technology } & \text { applications } \\
\text { and } & \text { technological } \\
\text { innovation contributions }\end{array}$ \\
\hline \multirow{2}{*}{$\begin{array}{l}\text { Teaching } \\
\text { university }\end{array}$} & $\begin{array}{l}\text { Technology } \\
\text { application } \\
\text { teaching } \\
\text { type (general } \\
\text { undergradua } \\
\text { te college) }\end{array}$ & $\begin{array}{l}\text { Applied senior } \\
\text { professionals } \\
\text { (undergraduate } \\
\text { education and certain } \\
\text { postgraduate } \\
\text { education) }\end{array}$ & $\begin{array}{l}\text { Cultivate all kinds } \\
\text { of applied talents in } \\
\text { production, service } \\
\text { and management, and } \\
\text { have certain scientific } \\
\text { and technological } \\
\text { contributions }\end{array}$ & $\begin{array}{l}\text { Cultivate all kinds of } \\
\text { applied talents in } \\
\text { production, service and } \\
\text { management, and have } \\
\text { certain scientific and } \\
\text { technological } \\
\text { contributions }\end{array}$ \\
\hline & $\begin{array}{l}\text { Skills } \\
\text { teaching } \\
\text { university } \\
\text { (higher } \\
\text { vocational } \\
\text { college) }\end{array}$ & $\begin{array}{l}\text { Skilled, highly skilled } \\
\text { personnel }\end{array}$ & \begin{tabular}{l}
\multicolumn{2}{r}{ Cultivate all kinds } \\
of skilled talents \\
engaged in \\
production, service \\
and management on \\
the first line
\end{tabular} & $\begin{array}{l}\text { Cultivate all kinds of } \\
\text { skilled talents engaged in } \\
\text { production, service and } \\
\text { management on the first } \\
\text { line }\end{array}$ \\
\hline
\end{tabular}

That is, the total amount of production materials produced by the first category should be equal to the sum of the production materials consumed in the production of the two ministries: the total amount of consumption data produced by the second category should be equal to the sum of the consumption data required by the two major categories. These balances are the basic conditions for achieving simple reproduction in society.

$$
\begin{gathered}
\mathrm{I}_{(\mathrm{C}+\mathrm{V}+\mathrm{M})}=\mathrm{I}_{(\mathrm{C}+\Delta \mathrm{C})}+\mathrm{II}_{(\mathrm{C}+\Delta \mathrm{C})} \\
\mathrm{II}_{(\mathrm{C}+\mathrm{V}+\mathrm{M})}=\mathrm{I}_{(\mathrm{V}+\Delta \mathrm{V}+\mathrm{m} / \mathrm{x})}+\mathrm{II}_{(\mathrm{V}+\Delta \mathrm{V}+\mathrm{m} / \mathrm{x})}
\end{gathered}
$$

That is, the total amount of production materials produced by the first category, after compensating for the production materials consumed in the production of the two major categories, should be equal to the additional production materials of the two major categories: the total consumption data produced in category II, after compensating for the balance of the existing living expenses of the two major categories, is equal to the need for two major categories of increased consumption data due to expanded reproduction.

\section{Deepen Teaching Reform and Improve Employability}

The important goal of a university to establish a school is to meet the needs of talents in local economic and social development. In today's increasingly developed market economy, the basic knowledge and practical theory necessary for financial management careers are indispensable. Students' comprehensive literacy has received extensive attention, including the financial skills, entrepreneurial philosophy, professional ethics and social responsibility of financial workers. The orientation of the talent training medium in colleges and universities is not only in line with the demand for talents in the development of the market economy, but also in the actual situation of running schools. 
A. Deepen the reform of education and implement it to every college graduate. Under the demand of the talent market, all colleges and universities constantly update the talent education model. Starting from the national conditions and social conditions, based on the economic development and the needs of the society for talents, we will establish a unique talent training method and cultivate students' ability to analyze and solve problems. They are trained to be able to keep up with the development of modern science and technology.

Table 2 College Students' Comprehensive Ability Index System

\begin{tabular}{|c|c|c|}
\hline \multirow{4}{*}{$\begin{array}{l}\text { Comprehensive } \\
\text { ability index } \\
\text { system }\end{array}$} & I indexes & II indexes \\
\hline & $\begin{array}{l}\text { Basic } \\
\text { quality and } \\
\text { basic ability } \\
\text { B }_{1}\end{array}$ & $\begin{array}{l}\text { Comprehensive language competenceC } C_{11} \text { 、 psychological adjustment } \\
\text { ability }_{12} \text {, mathematical application abilityC } C_{13} \text {, economic legal thinking } \\
\text { ability }_{14} \text {, computer application capabilityC } C_{15} \text {, humanities literacyC16、 } \\
\text { physical fitnessC17、 Ideological and political quality and legal literacyC18 }\end{array}$ \\
\hline & $\begin{array}{l}\text { Professiona } \\
\text { l abilityB }_{2}\end{array}$ & $\begin{array}{l}\text { Knowledge system masteryC21 、 professional tool application } \\
\text { abilityC22 、 professional research abilityC23、 professional exploration } \\
\text { abilityC24、professional innovation abilityC25、Professional orientation } \\
\text { capacityC26 }\end{array}$ \\
\hline & $\begin{array}{l}\text { Innovation } \\
\text { and } \\
\text { practical } \\
\text { abilityC }_{3}\end{array}$ & $\begin{array}{l}\text { Interpersonal skillC31、 adaptive capacityC32、application abilityC33、 } \\
\text { decision-making abilityC34、innovation and lifelong study abilityC35、 } \\
\text { team-work abilityC36、organization and management abilityC37、critical } \\
\text { thinking skillC38 }\end{array}$ \\
\hline
\end{tabular}

The capacity development measurement scale is used to measure the various capabilities of the construction capability index factors. The three scales for college students, teachers, and employers are all based on the Likert 5-point scale system with 1 representing complete non-conformance and 5 representing complete compliance. Among them, the SA scale has 5 measurement items, and the TAI scale and UAI scale have 3 measurement items. The conceptual model of measurement theory is shown in Figure 1:

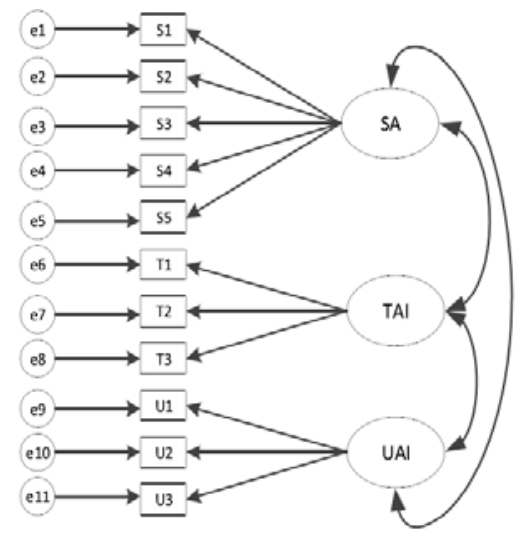

Figure 1 Measurement Theory Conceptual Model Diagram

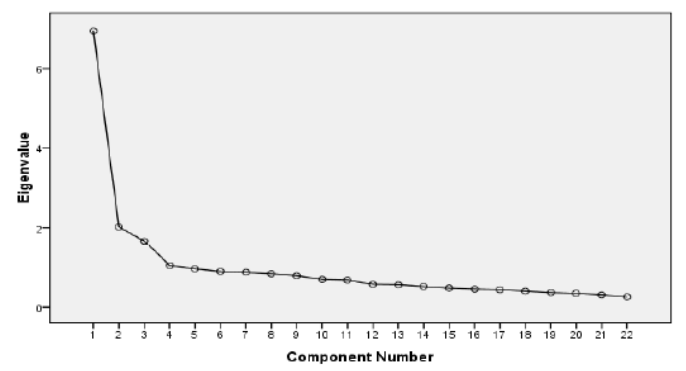

Figure 2 Common Factor Gravel Map 
The scale was analyzed by three factors, and the results showed that the explanatory variation of the eigenvalues of the three factors was $48.321 \%$. From the component matrix after the hinge, some projects have a large cross load on more than two factors, and delete them to perform the second factor analysis. Among them, the loads of "professional innovation ability" on factors 1 and 3 were extremely close $(0.448,0.445$ respectively, so the two topics were deleted. The third factor analysis was performed on the remaining 22 test items to obtain the load factor matrix, which was shown in Table 3:

Table 3 Rotation Component Matrix

\begin{tabular}{|c|c|c|c|}
\hline & One & Two & Three \\
\hline $\begin{array}{l}\text { Comprehensive language } \\
\text { competence }\end{array}$ & 0.639 & & \\
\hline $\begin{array}{l}\text { Psychological adjustment } \\
\text { ability }\end{array}$ & 0.662 & & \\
\hline $\begin{array}{c}\text { Matheatics application } \\
\text { ability }\end{array}$ & 0.599 & & \\
\hline $\begin{array}{l}\text { Economical and legal } \\
\text { thinking ability }\end{array}$ & 0.539 & & \\
\hline Computer skill & 0.609 & & \\
\hline $\begin{array}{l}\text { Hunanistic and scientific } \\
\text { literacy }\end{array}$ & 0.612 & & \\
\hline Physical fitness & 0.595 & & \\
\hline $\begin{array}{l}\text { Ideollogical and political } \\
\text { quality and legal quality }\end{array}$ & 0.568 & & \\
\hline $\begin{array}{c}\text { Ability to master } \\
\text { knowledge system }\end{array}$ & & 0.668 & \\
\hline $\begin{array}{c}\text { Ability to use } \\
\text { professional tools }\end{array}$ & & 0.648 & \\
\hline $\begin{array}{c}\text { Professional research } \\
\text { ability }\end{array}$ & & 0.568 & \\
\hline $\begin{array}{l}\text { Professional exploration } \\
\text { ability }\end{array}$ & & 0.632 & \\
\hline $\begin{array}{c}\text { Professional orientaion } \\
\text { ability }\end{array}$ & & 0.609 & \\
\hline Interpersonal skill & & & 0.679 \\
\hline Adaptive capapcity & & & 0.654 \\
\hline Application ability & & & 0.609 \\
\hline Decision-making ability & & & 0.643 \\
\hline $\begin{array}{c}\text { Innovative and lifelong } \\
\text { learning ability }\end{array}$ & & & 0.651 \\
\hline Team-work ability & & & 0.612 \\
\hline $\begin{array}{l}\text { Organization and } \\
\text { managment abilty }\end{array}$ & & & 0.623 \\
\hline Critical thinking skills & & & 0.679 \\
\hline Characteristic root & 5.492 & 2.103 & 1.749 \\
\hline The load of each factor & 24.083 & 29.486 & 38.941 \\
\hline
\end{tabular}

B. Further optimize the curriculum system based on the talent training model. There are many ways to train talents. When setting up courses, we should further optimize teaching reforms and scientifically and systematically change traditional teaching methods. The teaching module set up for innovative talents can effectively improve students' practical ability and theoretical level, and lay a foundation for student employment. The foundation is the basis of theory, and the major is the specialization of theory. Under the premise of practice, the two should be more optimized. Technical courses should be practice-based, allowing students to reach out to society in practice.

C. Highlight the application of practical education. Practice is the sole criterion for testing truth. Only through practical training can we draw correct conclusions. Practical education is the key to the 
cultivation of applied talents. In the integrated teaching mode of theory and practice, colleges and universities should select practical content according to the content of teaching, and give play to educational advantages according to the plasticity of talents. College teachers should systematically integrate teaching content. All knowledge and theory should exist in the framework of practice to realize the unity of theory and practice in teaching, to cultivate students' basic skills in limited practice, and to stimulate students' enthusiasm for learning.

\section{Conclusion}

Colleges and universities, especially those that cultivate applied talents, should reform the existing talent training model and put employment and talent training in a unified system plan. Only students should not be unemployed after graduation and have professional development. It is considered to be responsible to the students and to the society.

\section{References}

[1] Zhuo Zhi. Exploration on the Reform of Talents Training in Higher Financial and Economic Affairs__A Perspective of Aging and Lifelong Education [J].Journal of Shanghai Lixin Institute of Accounting and Finance, 2017(06):14-24.

[2] Chen Hao, Tang Huojian. General Knowledge-based Multi-integration Interdisciplinary Training of Composite Financial Talents [J]. Chinese University Teaching, 2017 (11): 31-33.

[3] Dai Jitao. Preliminary Study on the Cultivation of Financial and Legal Personnel under the "Belt and Road" Initiative__Based on the Practice of the First Group of Financial and Economic Colleges and Universities Selected as the Training Base for National Excellent Legal Talents[J].Legal Education Research,2017, 18(03): 17-31+371.

[4] Tian Guoqiang. The Idea and Practice of the Top-notch Model of Innovative Talents in Economics_-Taking Shanghai University of Finance and Economics as an Example [J].Higher Education Review, 2017, 5(02):18-24.

[5] Lin Hui. Data-Driven Research Report: A New Trend of Financial News in the Internet Age__Also on the Reform of Financial News Talents Training[J].Journalist, 2017(02): 64-68. 